To Cite This Article: Kahraman, M. (2019). Land use changes in Üsküdar according to pervititch maps. International Journal of Geography and Geography Education (IGGE), 40, 478-489.

\title{
LAND USE CHANGES IN ÜSKÜDAR ACCORDING TO PERVITITCH MAPS
}

\author{
Mustafa KAHRAMAN ${ }^{11}$
}

\begin{abstract}
Developing technology, like all other sciences, also influenced the science of historical geography. Thanks to developing information technologies, research questions in history and geography have become more quantitative and complete. The aim of the study is to find the land and residential usage patterns of the Üsküdar in the 1930s and to compare them with today's land and residential usage patterns. The study consists of two stages. Firstly, the 1/200 scale map prepared by J. Pervititch in 1930-1935 was geo-referenced with ArcGIS 10.1.1 program, and land use patterns were made. In the second phase, Üsküdar's land use patterns were digitized and compared with the insurance maps prepared by J. Pervititch. As a result of this, in the Uskudar in the 1930s, the total area of places such as garden, garden, house, place of worship, cemetery, the floor elevations of the houses and the physical conditions (old, new, demolished, wood, reinforced concrete), change in usage patterns were determined. In the 1930s, green areas, which accounted for $36 \%$, decreased. The main reason for this decrease is the disappearance of some cemeteries. On the other hand, the area occupied by the streets and streets has increased. The main reason for this is the construction of new streets and streets in empty fields. There have also been some changes in the characteristics of the roads over time. In the years 1930-1936, there were 142 dead-end streets in the study area. Today, the number of dead streets is 83 . The business and trade area of the city was also determined from the Pervitich maps. Between the years 1930-1936, the center of the city is the Üsküdar Pier. In the years 1930-1936, while the majority of the buildings were 1-2 storeys, it is now 5-6 storey. In the 1930s, an important part of the buildings was old and the number of buildings under construction is only one. The reason for this situation is the political and economic conditions of the period.
\end{abstract}

Keywords: Üsküdar, Land Use, Land Use Change, Pervititch, GIS

\footnotetext{
${ }^{1}$ Res. Asst., i̇stanbul University, Faculty of Literature, Department of Geography, İstanbul, Turkey., https://orcid.org/0000-0003-3792-1084., mustafa.kahraman@istanbul.edu.tr
} 


\section{INTRODUCTION}

Historical maps and geographical information systems, which are used more and more every day in historical geography studies, can offer researchers the basis of spatial change based on quantitative information (Buckley, Barnes and Richard, 2007; López, 2016; Travis, Lunen, 2012; Statuto, Cillis and Picuno, 2017; Gregory and Healey, 2007; Schaffer and Levin, 2015; Petrie, Orengo, Green, Walker, Garcia, Conesa, Knox and Singh, 2018). Historical map of contemporary maps overlaid and the examing spatial changes in the world and Turkey tried many times and reached the interesting information (Reis, Nişanci, Uzun, Yalçın, İnan and Yomralıoğlu, 2003; Saglam And Ayhan 2005; Celikoyan, Sertel, Seker, Kaya and Alganci, 2011; Atabeyoğlu, 2016). However, such an application has not yet been made for Üsküdar. In this respect, it is hoped that this study will close a deficiency in the research.

The study area is the southwestern part of the Üsküdar district of Istanbul (Figure 1). This is the site where Üsküdar city was located in the 1930s. It covers a total area of $7.23 \mathrm{~km}^{2}$. The main factor that played a role in the selection of this area is that all of the map sheets showing the Üsküdar can be reached. There are significant shortcomings in maps showing other parts of Istanbul.

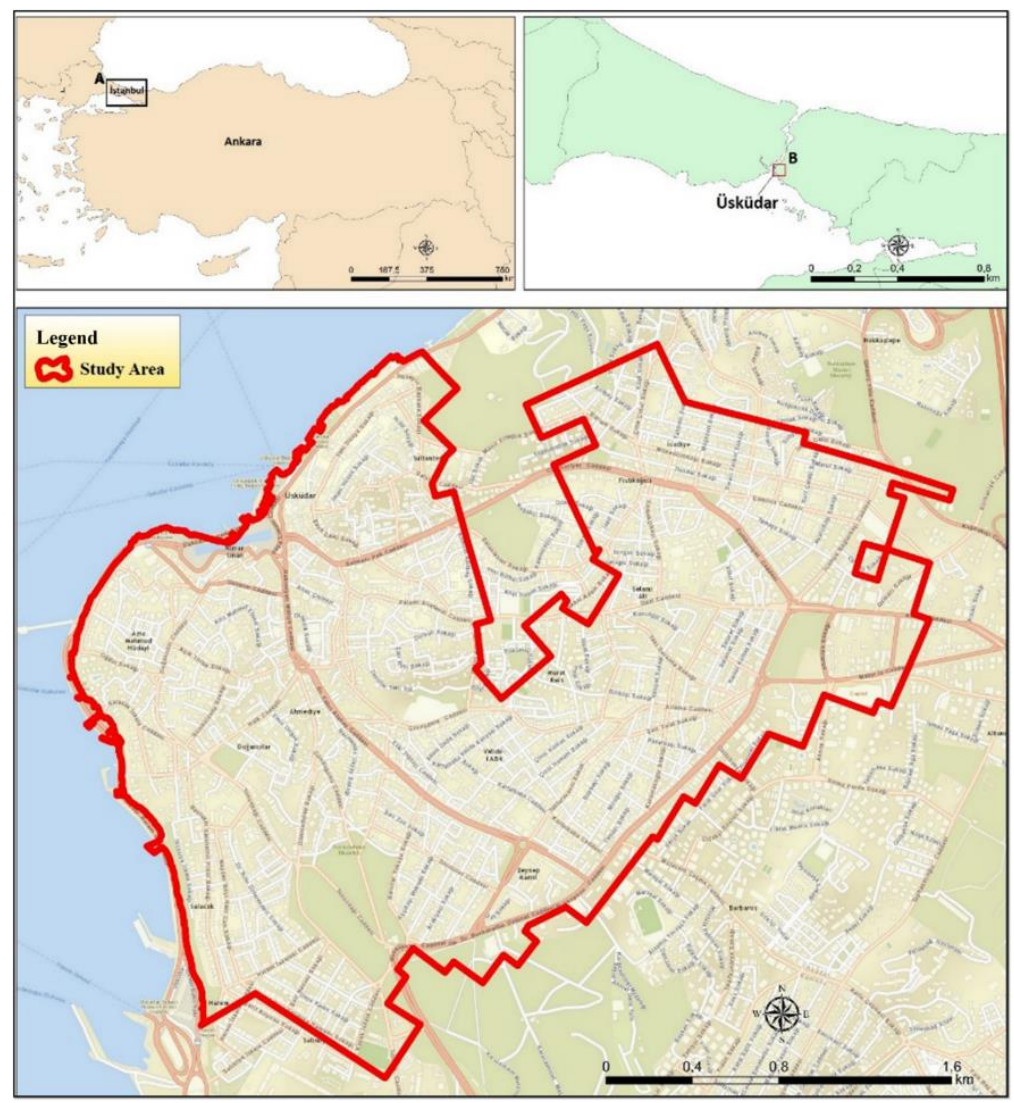

Figure 1: Location Map

\section{SOURCES}

Materials used in the study were prepared by the Hungarian cartographer Jacques Pervititch between 1920 and 1940. Pervititch has prepared these maps for insurance companies of the period (Batur, 2001: 4). One of the biggest catastrophes for Istanbul in the early 20th century is a fire (Cezar, 1963: 327). Pervititch's maps contain the risk elements of the field against fire. In the maps, the factors that will reduce or increase the rate of damage in the case of a fire such as the building material and the purpose for which the building is used, whether it is close to water structures such as fountains, water fountains, etc. are indicated. Although Pervititch has mapped all of Istanbul at that time, only Üsküdar maps were used in this study (Figure 2). 


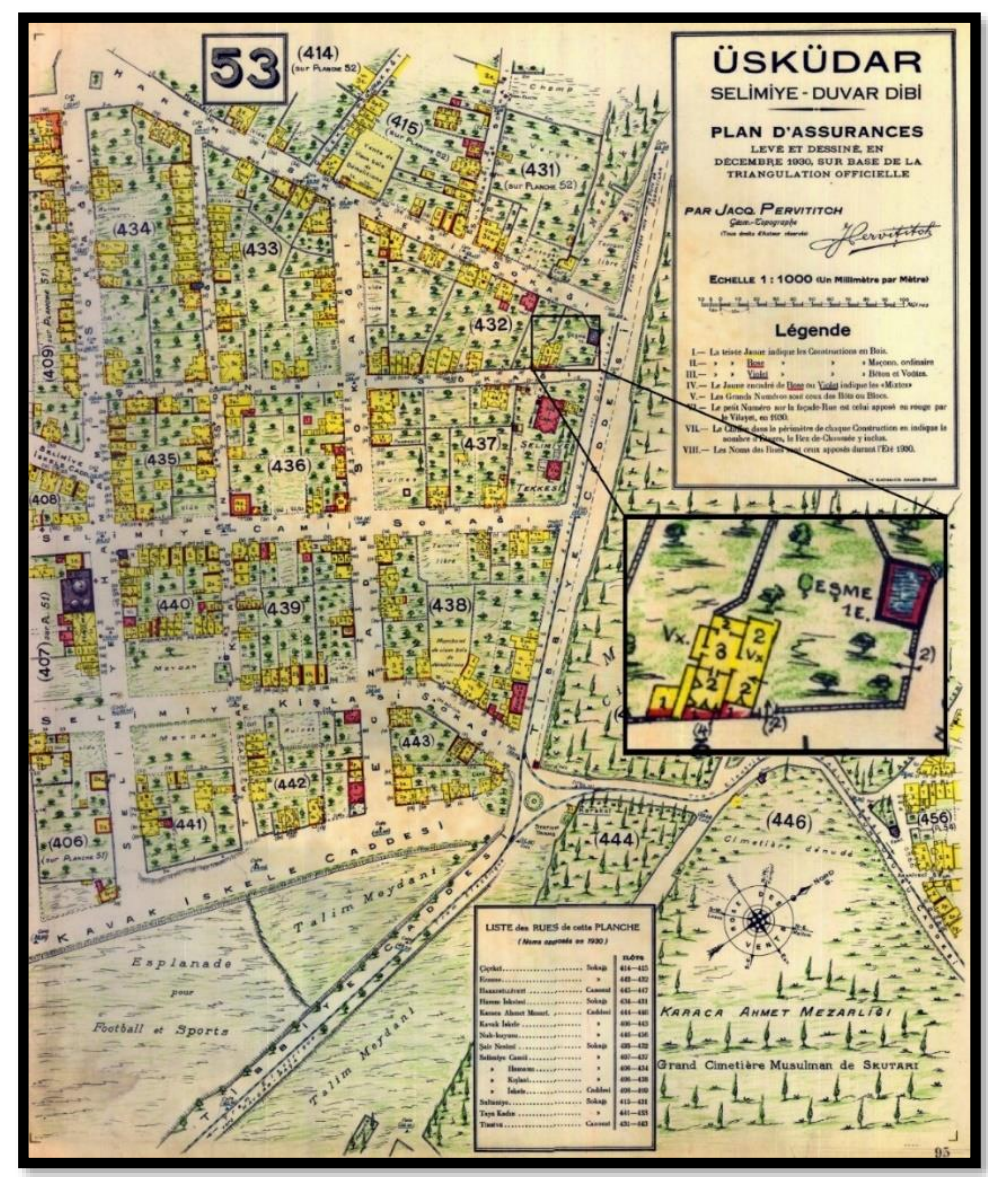

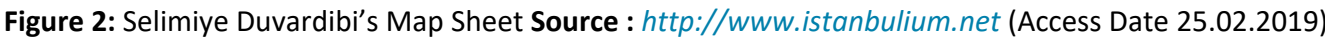

Turkish and French as a language used in map sheets. The areas shown in yellow in the maps indicate that the structure is wood, while the red colors indicate that the building is stone. The figures written on the buildings indicate the number of floors of the houses. Vx on structures is the abbreviation of vieux, the old French word. In rare cases, the letter $\mathrm{N}$ on some buildings was used as an abbreviation for neuf. The meaning of neuf is new.

The maps showing Üsküdar are 25 pieces, and they are 1/200 scale. The historical period of Figure 1 is 1930-1935. Although a large part of the Pervirich maps has survived to the present day, not all of the sections are available. Only one sheet is missing. Another feature of Üsküdar layouts is that it reflects a short period like 1930-1935. These two reasons have also been an important factor in location selection.

\section{METHOD}

The method part consists of two stages. The current historical maps are coordinated with the ArcGIS 10.1.1 program using the WGS84 Web Mercator (Auxiliary Sphere) projection, and each item on the map is digitized (Figure 1). As a result of this digitization, 14 different building types and 16 land use models were used in layouts for different purposes. The area covered by each of the identified land use patterns was calculated in $\mathrm{m}^{2}$.

The second method used in the study is remote sensing techniques applied to detect the current situation. In order to determine the current land use, the current satellite photographs and the plans and building usage investigation system on the Üsküdar Municipality website were used (Üsküdar Belediyesi, 2018). 9615 buildings within the working area were digitized manually and data was entered into the buildings.

\section{USKUDAR LAND -USE PATTERNS}

"Land Used all forms, activities, and inputs made on the use of people from the earth by the interactions between natural environment and human, or all arrangements, activities, and inputs made on a specific land cover type; We can define the management choice of the land for social and economic purposes are" (Gülersoy, 2002: 49-128). Maps depicting Üsküdar in the years 1930-1935, It 
covers an area of $7229350 \mathrm{~m}^{2}$ (Figure 1). According to the information on the Pervititch maps, land use patterns were removed from this area. These land use patterns:
1. Green Areas
2. Cemeteries
3. Empty Spaces
4. Roads
5. Business and Trade Center is considered.

\section{Green Areas}

The total area of the green areas in Üsküdar in 1930-1935 is $2637414 \mathrm{~m}^{2}$ and it corresponds to 36\% of the land use. Green areas can be varied. These green areas, according to the areas they occupied, from large to small, the gardens of houses $(61 \%$ of green areas), field ( $19 \%$ of green areas), garden ( $13 \%$ of green areas), garden ( $4 \%$ of green areas), fruit and vegetable garden ( $1 \%$ of green areas), park ( $1 \%$ of green areas), flower garden ( $1 \%$ of green areas), Tree (less than $1 \%$ of green areas).

While the gardens and orchards were usually found in the Bülbüldere and Çavuşdere Valley for that period, the fields were concentrated on the north-east of Üsküdar (Figure 3). Probably dry farming is done here.

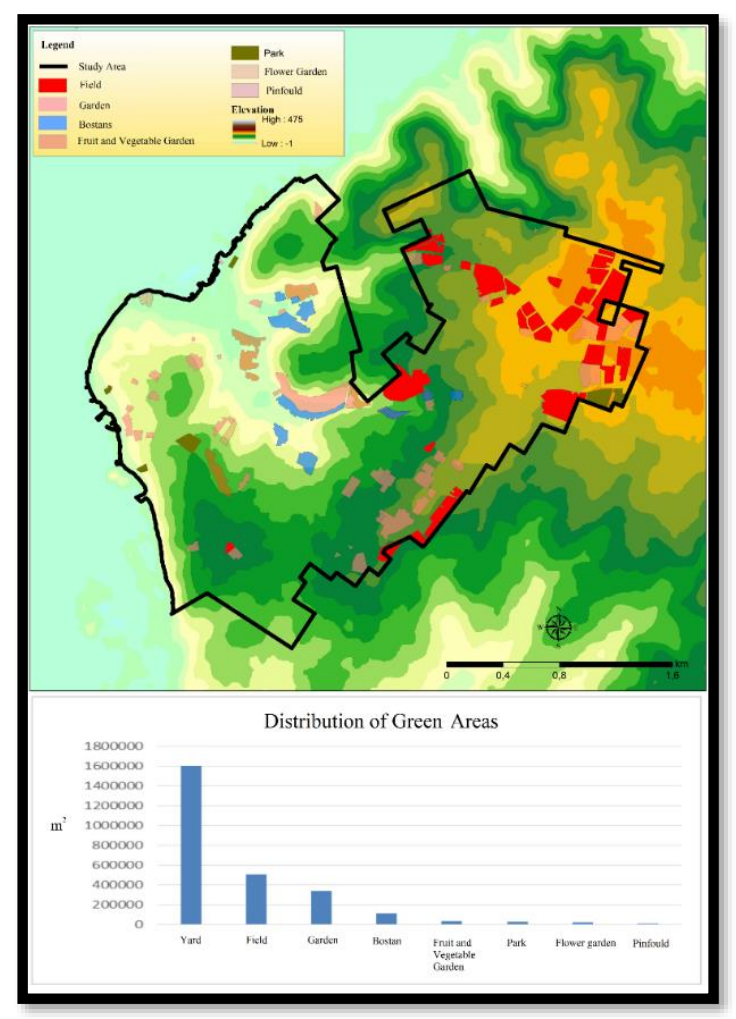

Figure 3: Distribution of Green Areas in Üsküdar (1930-1935)

\section{Cemeteries}

The area covered by cemeteries in Üsküdar in 1930-1935 is $400463 \mathrm{~m}^{2}$. In other words, it corresponds to $6 \%$ of the total working area. Today, this area has decreased by $14 \%$ and the area covered by the cemeteries has decreased to 344699 $\mathrm{m}^{2}$. The main reason for this decline is the disappearance of the Selamsız cemetery located in the neighborhood of Murat Reis and the emergence of residential areas (Figure 4). Another example is Hakimiye Street. It is on a roundabout at the intersection of Fahri Atabey Avenue.

The cemetery, which is the most altered area in the period from the 1930s to the present day, is the Üsküdar Greek Armenian Cemetery. The probable cause is the protection of minority rights in accordance with Article 42 of the Treaty of Lausanne (TBMM, 2019). 


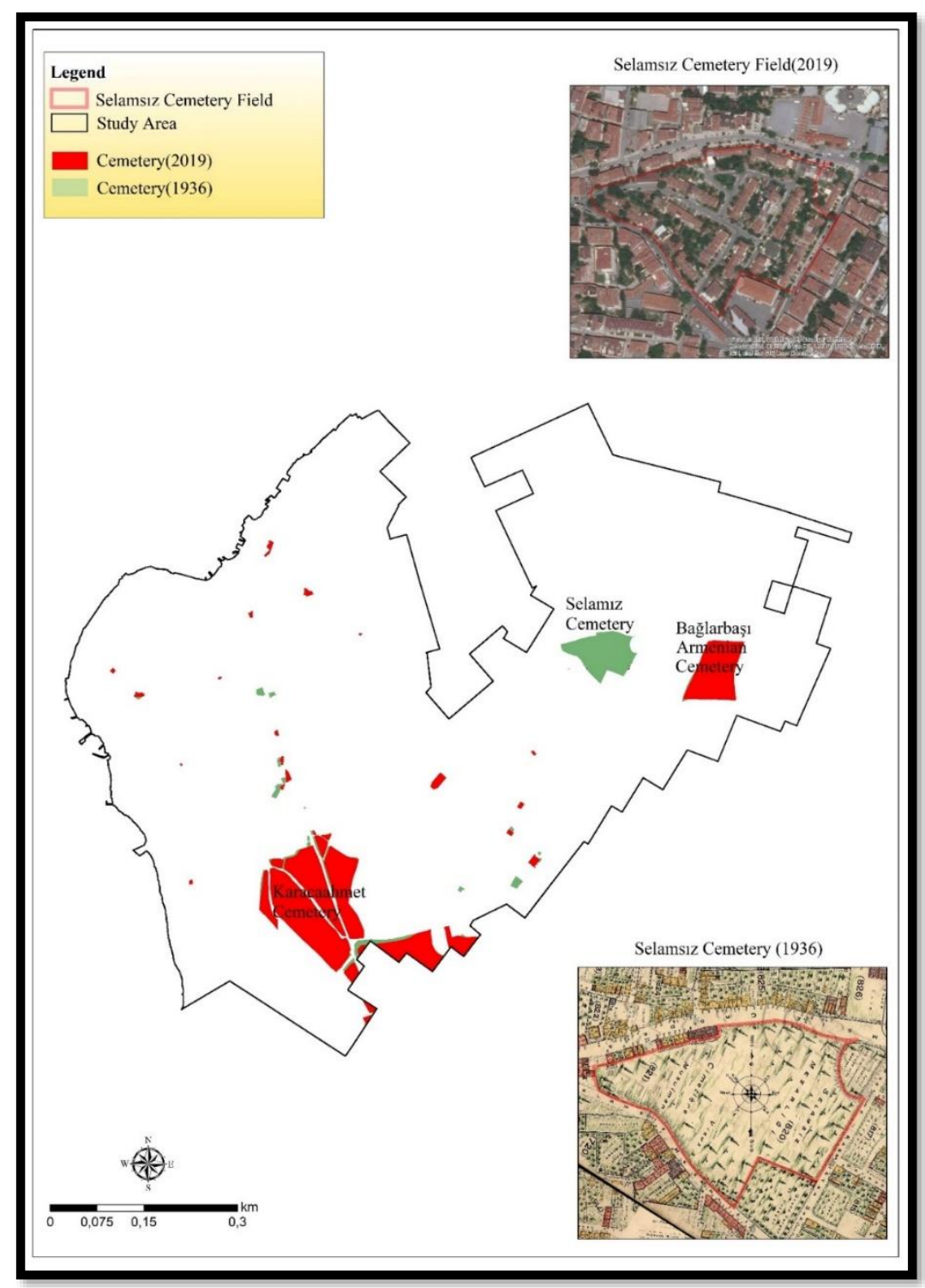

Figure 3: Cemeteries in the Working Area

\section{Empty sites}

There are also many vacant areas in Üsküdar outside the green fields. For the empty areas, the map layouts had some land, slope, slope area, cliff, and some areas were left blank. The area covered by all these empty areas is $1434115 \mathrm{~m}^{2}$ and corresponds to $20 \%$ of the working area (Figure 4).

While there was so much free space in the absence of population pressures, these places are now open to settlement in the face of increasing housing need. Today's Üsküdar, such events are challenging to come across. 


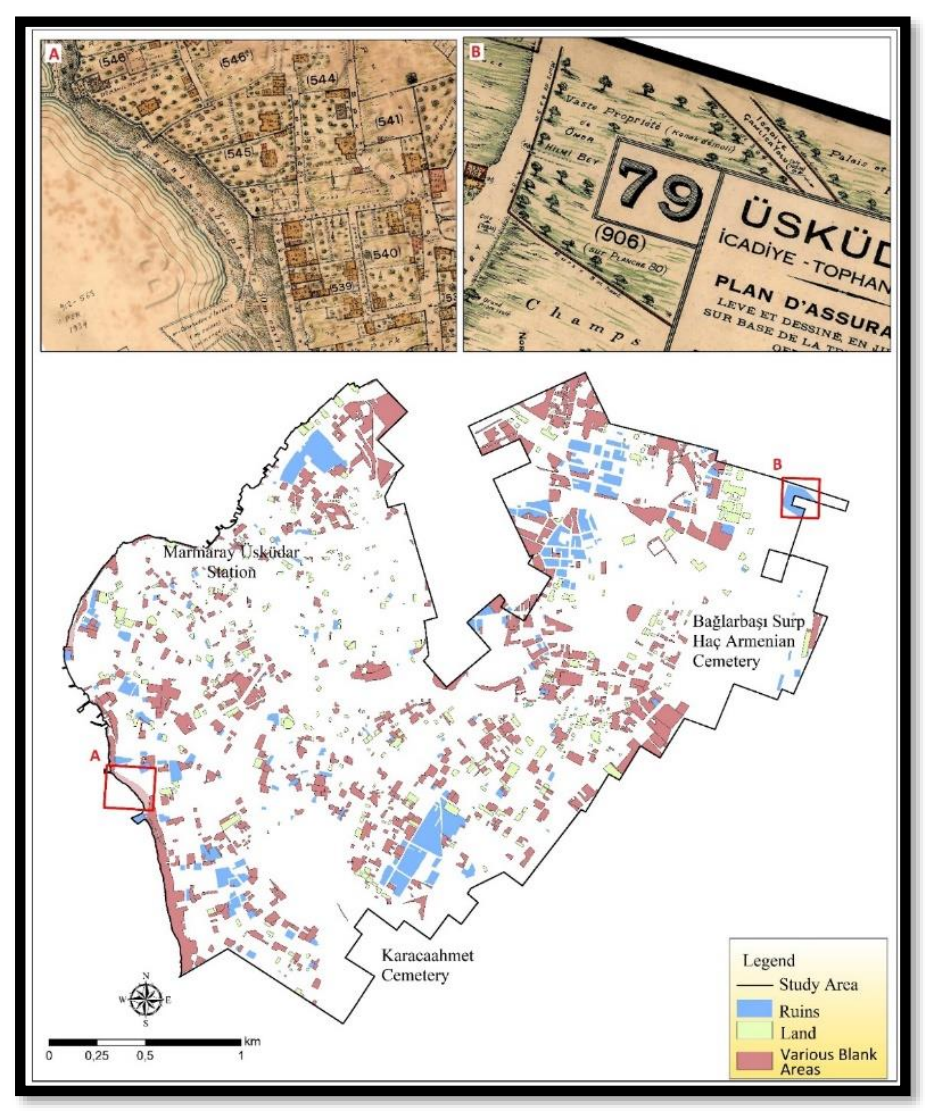

Figure 4: Empty Sites in the Study Area

\section{Roads}

Roads in the years 1930-1935 in Üsküdar area of the streets covered in area $1279486 \mathrm{~m}^{2}$ and the total length of the way is $117137 \mathrm{~m}$. When we look at the present day, the area covered by the road is $2011821 \mathrm{~m}^{2}$, and the total road length is 142533 meters. While the roads covered $18 \%$ of the study area in the years 1930-1935, today the roads constitute $28 \%$ of the study area. As the streets and streets approached to the present day, the total road length increased with the expansion of the new roads.

The majority of Üsküdar in 1930-1935 is located in a valley. Therefore, the slope values of the roads are also affected. While the average slope value of the roads in 1930-1935 is 5.4 degrees, the inclination of the roads in 2018 is 6.4 degrees. The main reason for the emergence of such a result is the opening of the empty sloping lands in 1930-1935 to the settlement and making the roads there.

As the length of the roads and the area they occupied expands, the number of dead-end streets has decreased. While there were 142 dead-end streets in the study area in total between 1930-1935, the number of dead streets is 83 (Figure 5). The main factor in the formation of dead-end streets is the privacy request of people. The dead-end generally uses people who live in the neighborhood. The foreign people entering the street are easily noticed. Hence the dead-end streets become less public than the open streets (Yoldaş, 2017: 17).

However, in the modern planning concept, dead-end streets are not required (Çetin, 2012: 89). The work done for the removal of the dead-end streets of Istanbul is going back to the 19th century. In this century, the laws and regulations such as 1948, 1949 Ebniye Nizamnamesi, 1882 Ebniye Kanunu have been enacted in order to prevent and eliminate the dead-end streets (Yörüten, 2018: 15). As a result of all these efforts, the number of dead streets has decreased. 


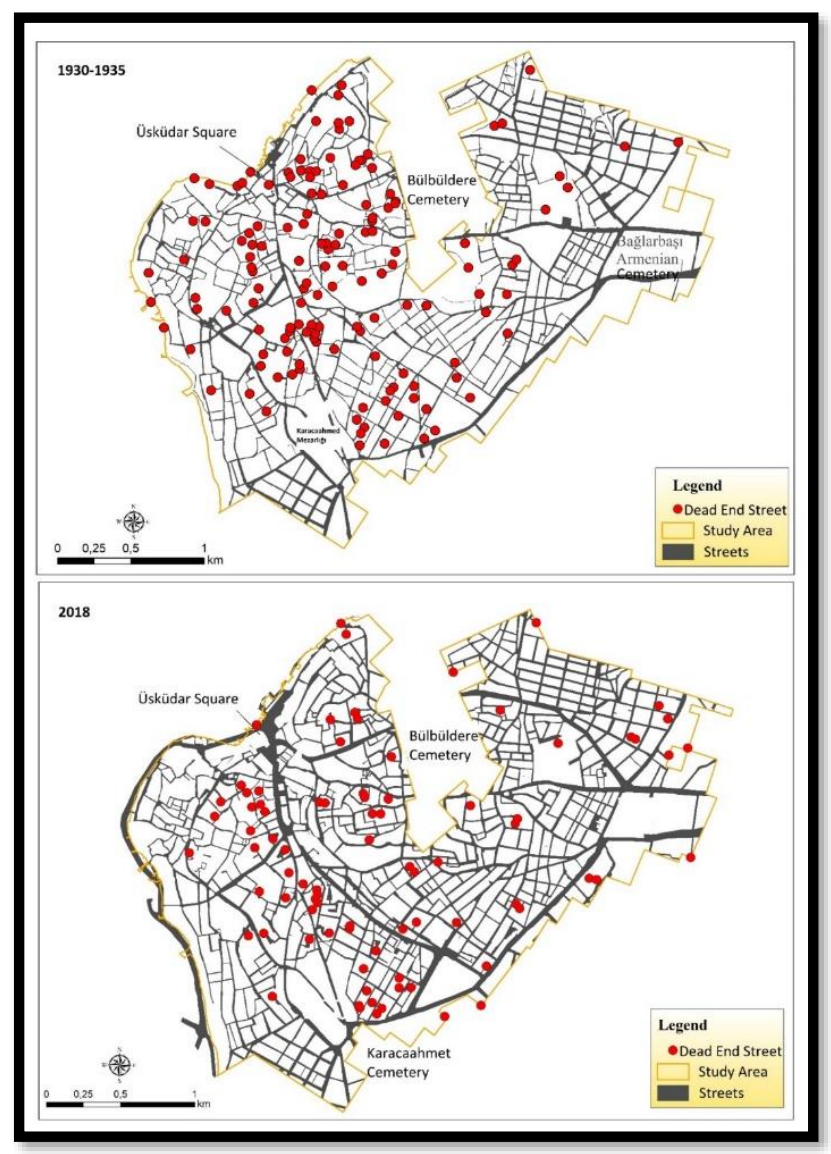

Figure 5: Dead End Streets

\section{Central Business District}

In urban geography studies, determining the central business area of the city is a critical situation. In 1930-1935, the central business area is Yeni Valide Mosque. Last 82 years, the business and trade center in Üsküdar has been expanded exponentially. In addition, the new business and commercial center are located in the area to the west of the Istanbul Ring Road. The main reason for the emergence of this center is the 15 July Martyrs' Bridge, which was opened in 1973, and the Istanbul Ring Road, which is the connection road of the bridge, has passed from here (IMO, 2019) (Figure 6).

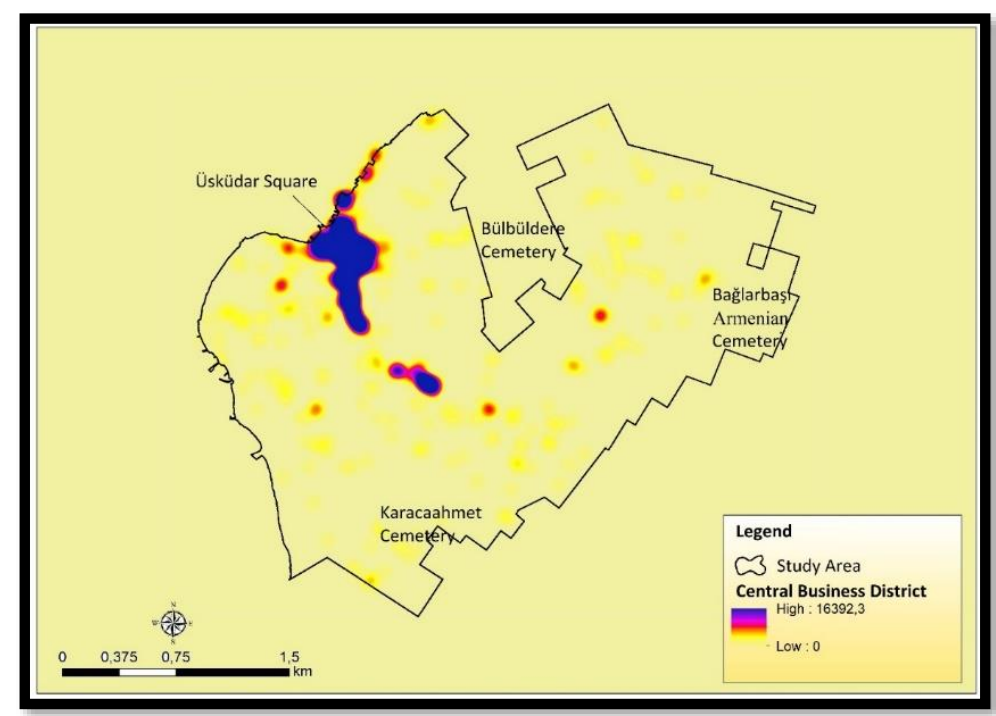

Figure 6: Central Business and Commercial Sites (1930-1935) 


\section{STRUCTURES IN THE FIELD OF WORK}

In 1930-1935, 19\% of the working area was found with buildings, and the rest of the building consisted of elements such as garden, field, cemetery, park, and roads. When we look at the current situation, the area occupied by the buildings corresponds to $38 \%$ of the total area.

In 1930-1935, the total number of buildings was 8 617. Today, there are 9190 buildings. In both periods, buildings were mostly used as housing (Table 1 ).

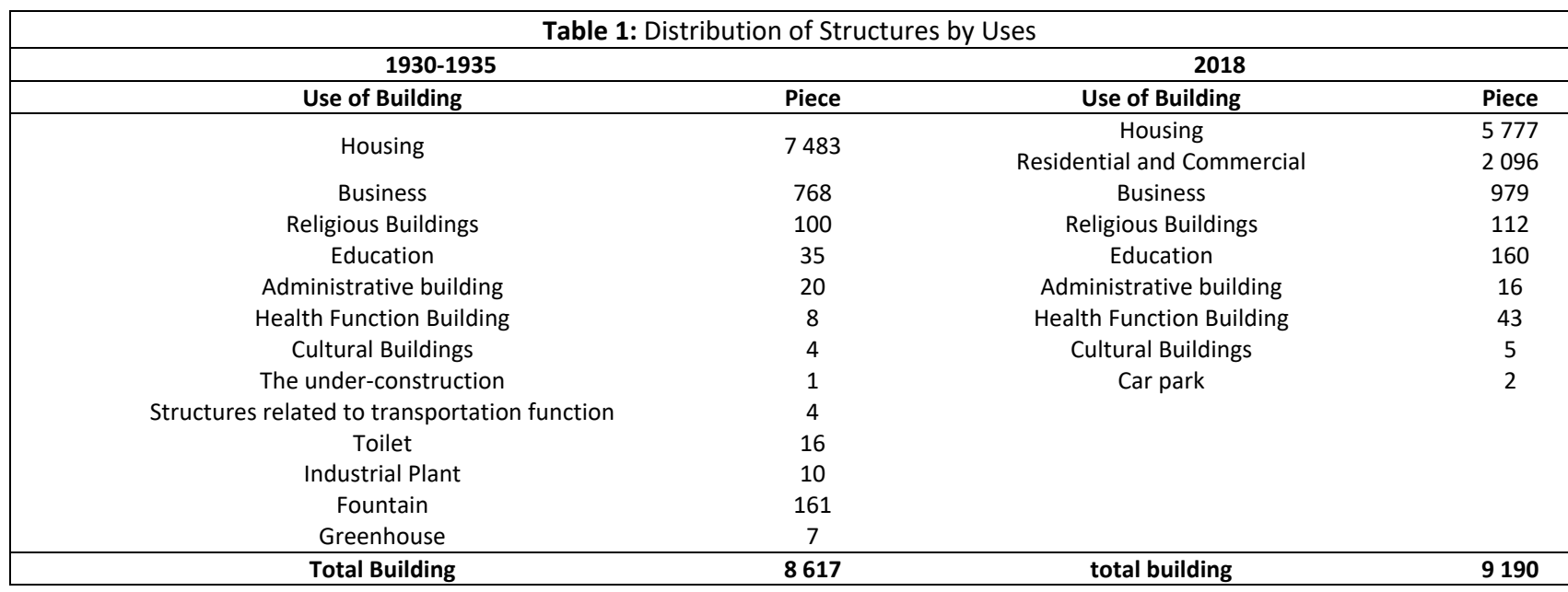

Pervititch maps have a lot of data about the properties of buildings. Since the prepared maps are used in order to determine the risk situations of fire and other natural disasters, in particular, some data such as the number of floors, how old it is, and what the construction material is identified. Under this heading, floor heights, age of buildings and building materials of buildings will be analyzed.

\section{Floor heights of buildings}

The growth of a city does not occur only laterally. Cities are growing in the vertical direction over time. Due to the lack of historical cartographic data, the determination of vertical growth is more difficult than determining horizontal growth. But Pervititch maps provide numerical data that can detect vertical growth.

Nearly half (48\%) of 8332 buildings in Üsküdar layouts of 1930-1935 are two storeyies. One-storey buildings account for $34 \%$ of total buildings and three-storey buildings constitute $17 \%$ of total buildings. The buildings with floors 4 and above correspond to only $1 \%$ of the total buildings. The building, which has the highest number of floors, is a 6 -storey tobacco company. Today, the tallest buildings with the highest number of floors are adjacent to the business and trade center as expected. Nowadays there are buildings up to 12 floors high in Uskudar. The maximum number of floors is 5 (Figure 7).

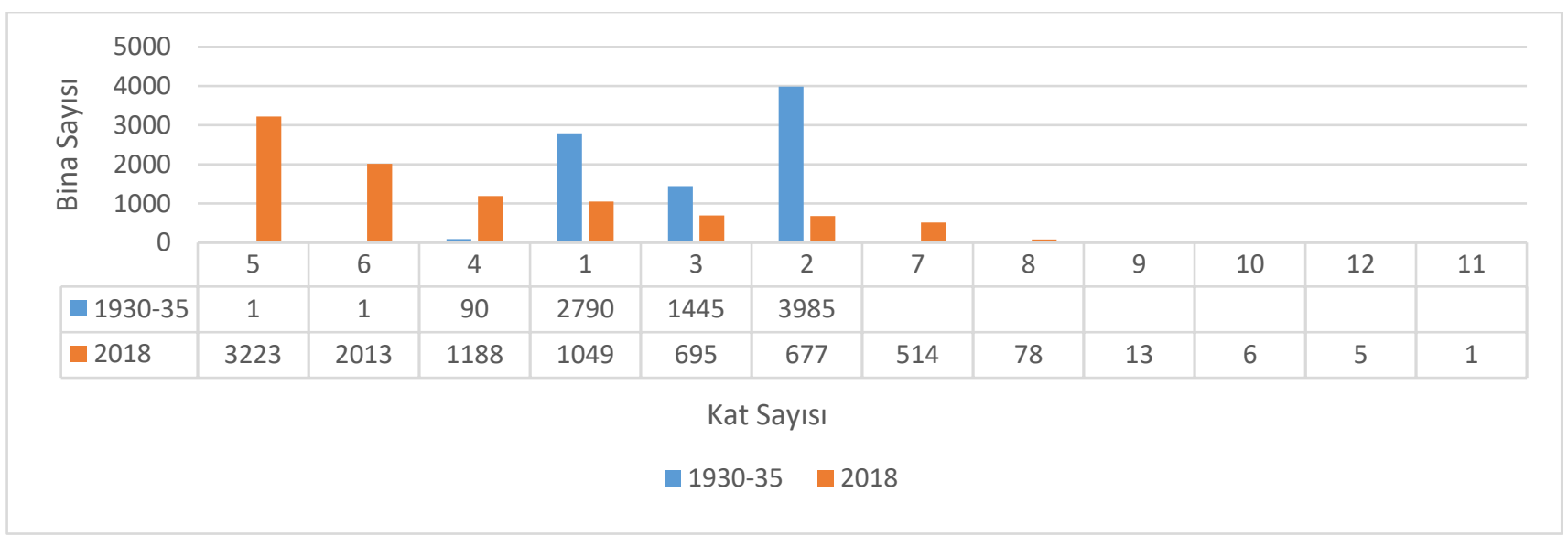

Figure 7: Number of Floors of the Worksite 
In the image of 1930-1935, it is observed that single-storey buildings generally concentrate in the center of the city. In 2018 , the number of floors increased in the reverse of the 1930 s in places considered as business and commercial sites (Figures 8 and 9).

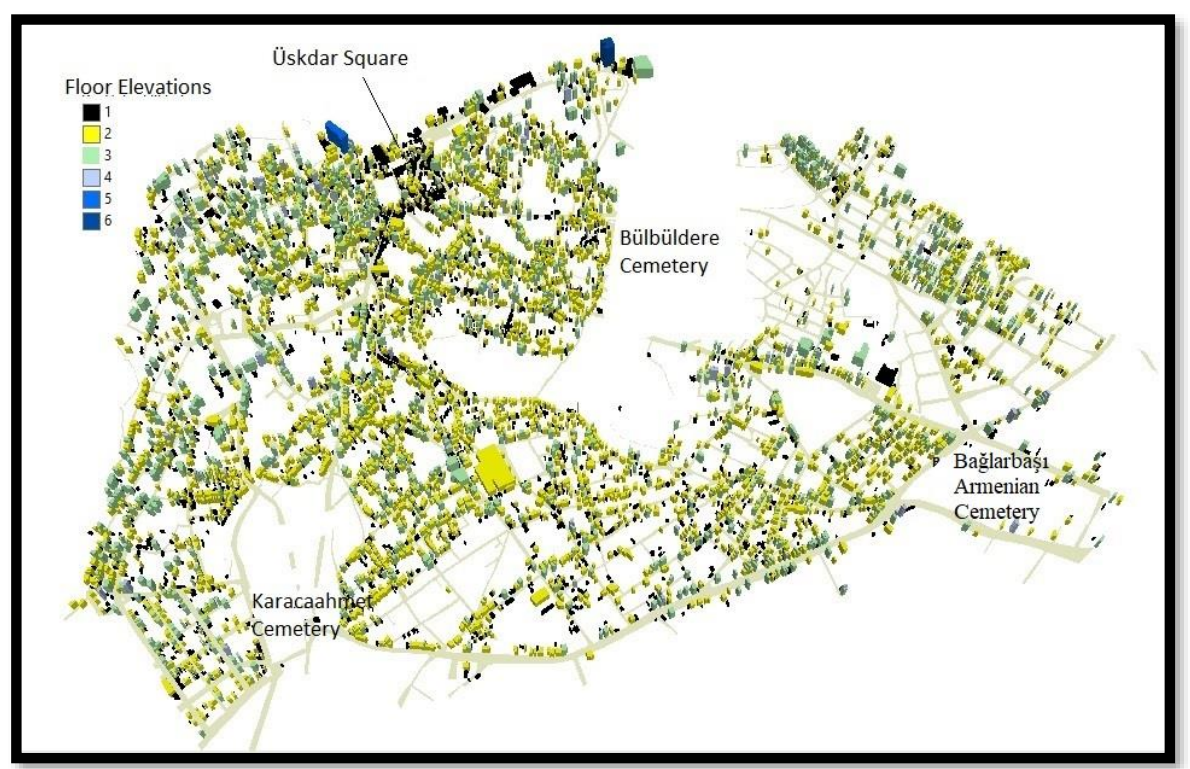

Figure 8: Floor Elevations (1930-1935)

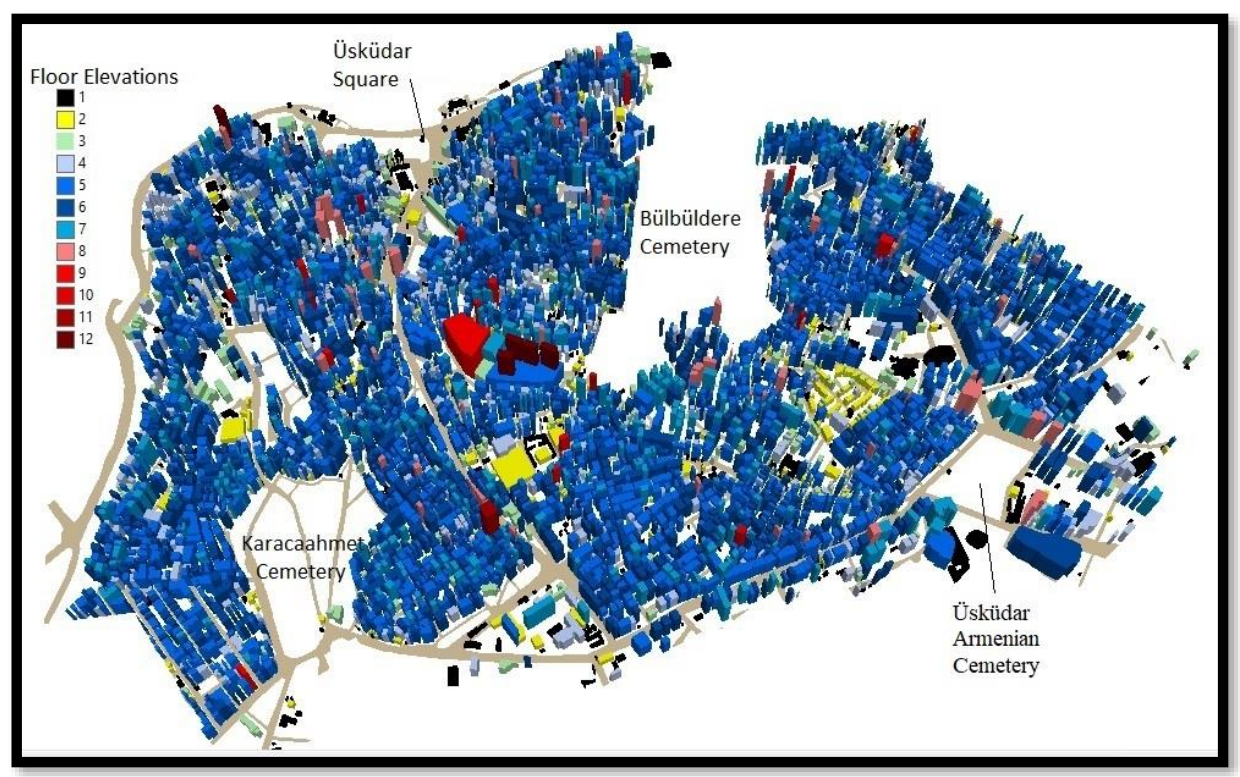

Figure 9: Floor Elevations (2018)

\section{Building Age}

One of the first things we look at in the Pervititch maps is that there are many idle areas in Üsküdar. $4 \%$ of the study area is called ruin. Not only idle areas but $13 \%$ of the buildings were recorded as old buildings (Figure 10). Only 1\% of the buildings in the period when the maps were prepared were registered as new buildings (Table 2). The formation of such idle areas in Üsküdar between 1930 and 1935 and the emergence of older buildings are much more related to the economic and political situation of the period. This is the reason why the population is low because the new republic was established, and the economic crisis of 1930. 


\begin{tabular}{|c|c|c|c|c|}
\hline Building Type & New & ancient & The under construction & Half Destroyed \\
\hline Housing & 57 & 1051 & & 2 \\
\hline Business & 8 & 82 & 1 & \\
\hline Place of worship & & 11 & & \\
\hline Educational Buildings & 2 & 2 & & \\
\hline Administrative Buildings & 1 & 4 & & \\
\hline Industrial Function Related Buildings & & 1 & & \\
\hline Cultural Buildings & & & & \\
\hline Transport Function Related Buildings & & & & \\
\hline Health Function Buildings & & & & \\
\hline Not Specified & & & 1 & \\
\hline Total & 68 & 1151 & 2 & 2 \\
\hline
\end{tabular}

In the 1930s, Üsküdar, especially in Istanbul, remained in an idle state, but the fact that it lost its administrative function together with the republic. Istanbul's population in the first years of the Republic is 700,000 . However, there is an infrastructure where one and a half million people can live. Therefore, there was a surplus of housing rather than a housing need.

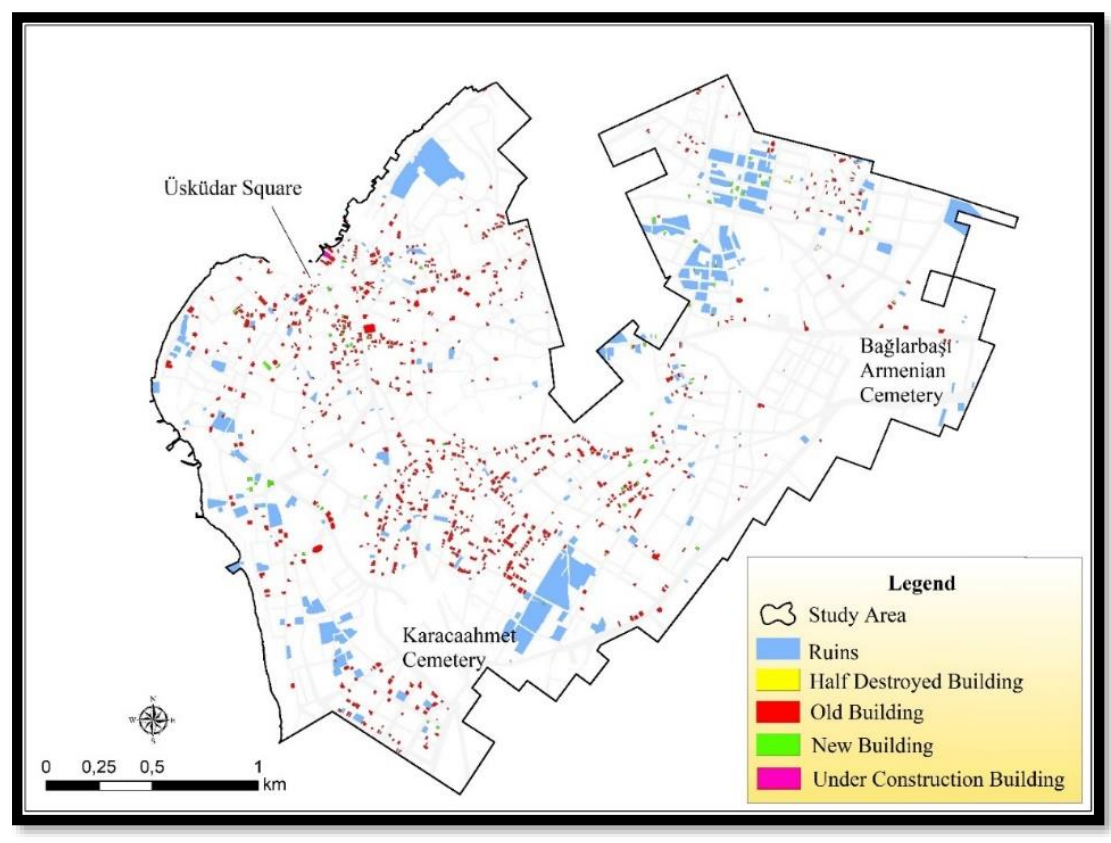

Figure 10: Status of Buildings (1930-1935)

\section{Building Material of Buildings}

Today, mostly in Üsküdar, the buildings are reinforced concrete. However, $85 \%$ of the buildings in Üsküdar in the years 1930-1935 were built like $15 \%$ stone, masonry, and reinforced concrete.

\begin{tabular}{|ccc|}
\hline \multicolumn{2}{|c|}{ Table 3. Building Types According to Building Material } \\
\hline Building Type & Wooden & Stone / Reinforced Concrete / Masonry \\
\hline Administrative Buildings & 8 & 12 \\
Housing & 6757 & 730 \\
Place of worship & 33 & 62 \\
Educational Buildings & 14 & 21 \\
Business & 329 & 429 \\
Cultural Buildings & 2 & 2 \\
Transport Function Related Buildings & 2 & 3 \\
Industrial Function Related Buildings & 4 & 6 \\
Health Function Related Buildings & 1 & 7 \\
\hline
\end{tabular}


It is noteworthy that the structures vary according to the choice of materials and the purpose of the use of the building. While most of the buildings used for housing were built from wood, wood was used less as a building material in buildings used for economic and cultural purposes (Table 3) (Figure 11).

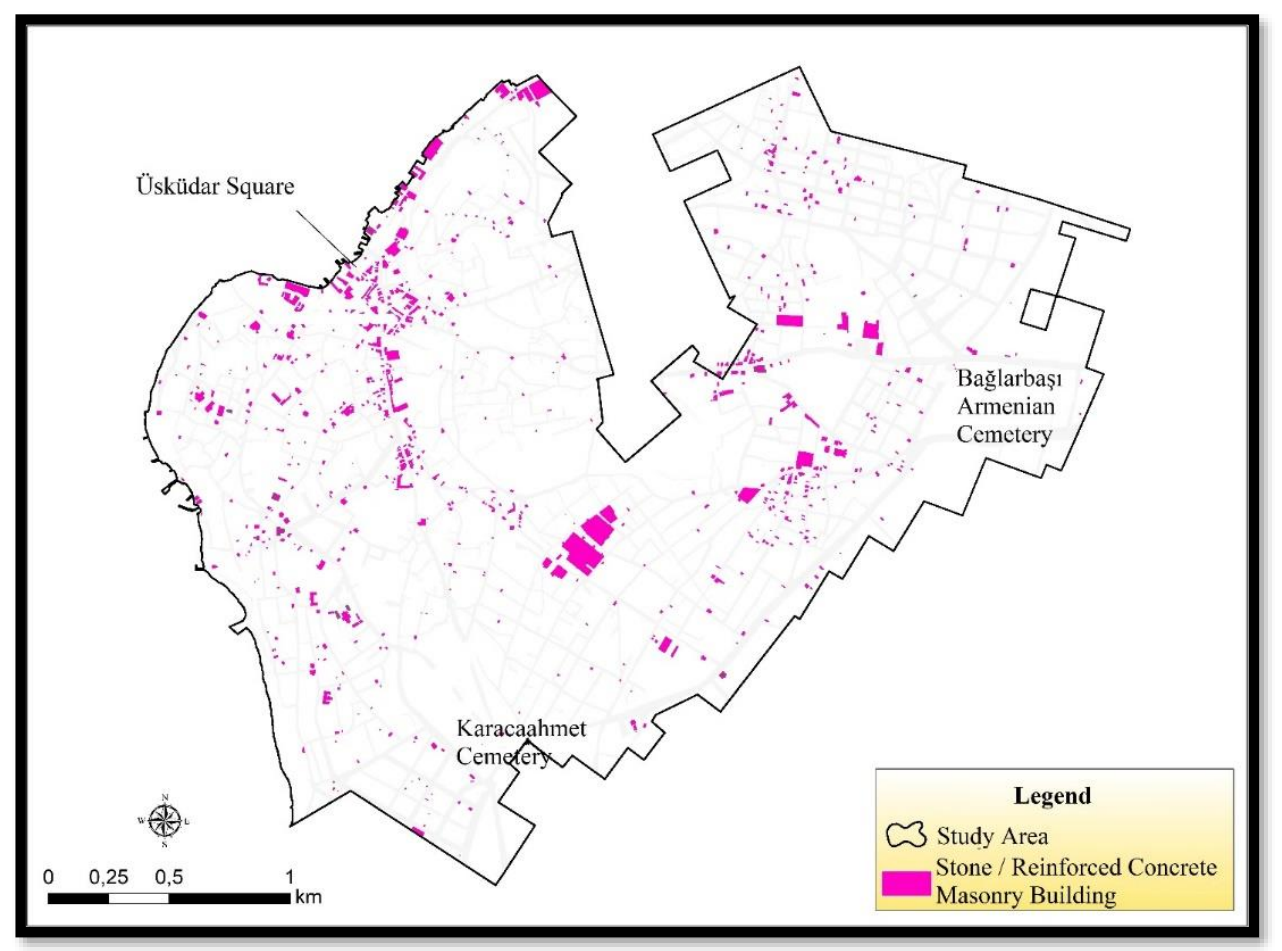

Figure 11: Building of Stone / Masonry / Reinforced Concrete Materials (1930-1935)

\section{RESULT}

Istanbul maps prepared by J. Pervititch cover the years 1922-1945. Üsküdar 's layouts were prepared in 1930-1936.

As a result of the coordinating and digitization of the layouts, it was possible to reach the numerical data on the physical conditions of the buildings constructed with the land use patterns in Üsküdar in the years 1930-1936, and this information was compared with today's conditions.

According to the maps of Pervititch, five land use patterns were determined between 1930 and 1936 in the form of green areas, cemeteries, empty spaces, roads and business, and trade center. Green areas cover an important area like $36 \%$ of the field in the 1930s In the period from 1930-1936, there have been changes in the cemeteries. Contrary to expectations, the cemeteries narrowed. The most important reason for the narrowing of the cemetery is the removal of the Selamsız Cemetery and the construction of residences. The most important reason for the narrowing of the cemetery is the removal of the Selamsız Cemetery and the construction of residences. One of the land use patterns, empty spaces can be a wide variety. Areas such as sloped fields, ruin areas, cliffs have been considered as empty sites. Roads, which are another land use pattern, covered $18 \%$ of the total land in $1930-36$ and now cover $28 \%$. The reason for this situation is the construction of roads in empty areas in the years 1930-1936. There have also been some changes in the characteristics of the roads over time. In the years 1930-1936, there were 142 dead-end streets in the study area, Today, the number of dead streets is 83 The business and trade area of the city were also determined from the Pervitich maps. Between the years 1930-1936, the center of the city is the Üsküdar Pier.

From the Pervititch maps, it is possible to reach a lot of information such as the height of the houses in the period, the building material, the purpose of use, whether the structure is new, old or ruined. In the years 1930-1936, while the majority of the buildings were 1-2 storeys, it is now 5-6 storey. In the 1930s, an important part of the buildings was old and the number of buildings under construction is only one. The reason for this situation is the political and economic conditions of the period. When the building materials of the buildings are examined, it is observed that most of the houses used as houses are wood. In constructions used for commercial purposes, wood material was used less proportionally. 
Pervititch maps can be used for many purposes other than those described above. However, in order to make these and similar studies more useful, it is thought that examining the comparison of Istanbul or other cities, in the same way, will provide an opportunity to produce sharper comments and theories in many disciplines such as history, geography and city science.

\section{Acknowledgments}

This study was presented from the 10th Üsküdar Symposium under the title of "Land Use in Üsküdar Between Two World Wars"

\section{References}

Atabeyoğlu, Ö. (2016). Reflections of 1904's Erzurum to current Erzurum. ITU A/Z, 13(2), 157-173.

Batur, A. (2001). Pervititch haritaları ya da Bir kenti okumak, Retrieved March 21, 2019, from http://earsiv.sehir.edu.tr:8080/xmlui/bitstream/handle/11498/16969/001511028006.pdf;jsessionid=AE61F2439FE4E8B57BF 306B54A3ABBB2? sequence $=1$.

Buckley, A., Barnes, D. \& Richards, J. (2007). Achieving historical map effects with modern GIS. Cartographic Perspectives, 56(56), 6372.

Celikoyan,T. M., Sertel, E., Seker, D. Z., Kaya, S. \& Alganci, U. (2011). Investigation land use changes in megacity İstanbul between the years 1903-2010 by using different types of spatial data, FIG Working Week 2011 Bridging the Gap between Cultures Marrakech, Morocco, 18-22 May 2011.

Çetin, S. (2012). Geç Osmanlıdan erken cumhuriyete iç batı anadolu'da kentsel yapının değişimi: Manisa, Afyon, Burdur ve Isparta kentleri, üzerine karşılaştırmalı bir inceleme. METU JFA, 29(2), 89-126.

Cezar, M. (1963). Osmanlı devrinde Istanbul yapılarında tahribat yapan yangınlar ve tabii afetler. Türk Sanat Tarihi Araştırma ve incelemeleri, 1, 327-414.

Gregory, I. N. \& Healey, R. G. (2007), Historical GIS: structuring, mapping and analysing geographies of the past. Progress in Human Geography, 31(5), 638-653.

Gülersoy, A. E. (2002). Yanlış arazi kullanımı. Elektronik Sosyal Bilimler Dergisi, 1(2), 49-128.

iMO, (2019). Retrieved March 21, 2019, from http://www.imo.org.tr.

ISTANBULIUM, (2019). Retrieved March 21, 2019, from http://www.istanbulium.net .

López, G. A. (2016). On georeferencing old maps: online map libraries and open source GIS, In book: Crisis, globalization and social and regional imbalances in Spain Editors: Spanish Committee International Geographical Union.

Petrie, C. A., Orengo, H. A., Green, A. S., Walker, j. R., Garcia, A., Conesa, F., Knox, J. R. \& Singh, R. N. (2018). Mapping archaeology while mapping an empire: using historical maps to reconstruct ancient settlement landscapes in modern India and Pakistan. Geosciences, 9(11), 126.

Reis, S., Nışncı, R., Uzun, B., Yalçın, A., Inan, H. \& Yomralıoğlu, T. (2003). Monitoring land -use changes by GIS and remote sensing techniques: case study of Trabzon. 2nd FIG Regional Conference Marrakech, Morocco.

Saglam, A. (2005). Developing a geographic information system for the Gallipoli campaign. (Master thesıs, Mıddle East Technıcal Unıversıty). Retrieved from https://tez.yok.gov.tr/UlusalTezMerkezi/.

Schaffer, G. \& Levin, N. (2015). Challenges and possible approaches for using GIS as a tool in historical geography landscape research: a meta-analysis review. e-Perimetron, 10(3), 94-123.

Statuto, D., Cillis, G. \& Picuno, P. (2017). Using historical maps within a GIS to analyze two centuries of rural landscape changes in southern Italy. Land 6, 65-80.

TBMM, (2019). Retrieved March 21, 2019, from https://www.tbmm.gov.tr.

Travis, C. \& Lunen, A. V. (2012). History and GIS: Epistemologies, Considerations and Reflections. London: Springer.

ÜSKÜDAR, (2018). Retrieved March 21, 2019, from https://cbs.uskudar.bel.tr/eharita/\# .

Yoldaş, N. G. (2007). Anadolu geleneksel konut dokusundaki çıkmaz sokak işlevinin günümüzdeki durumunun irdelenmesi, (Master thesıs, Selçuk University). Retrieved from https://tez.yok.gov.tr/UlusalTezMerkezi/.

Yörüten, G. \& Hamamcıoğlu, C. (2018). 19. yüzyılda düzenlenen istanbul Tarihi Yarımada'daki Ayvansaray ve Samatya yangın alanlarında günümüzdeki kentsel dokuların incelenmesi ve karşılaştırılması. Kent Akademisi, 11(33), 11-28. 